\title{
India's COVID-19 vaccination programme: challenges and solutions
}

\author{
Deodatt M. Suryawanshi*, Raghuram Venugopal, Suguna Anbazhagan, \\ Divya Rajseharan, Gayathri Kumar
}

Department of Community Medicine, Trichy SRM Medical College Hospital and Research Centre, Trichy, Tamil Nadu, India

Received: 27 May 2021

Revised: 10 June 2021

Accepted: 11 June 2021

\section{*Correspondence:}

Dr. Deodatt M. Suryawanshi,

E-mail: drdeodattms1983@gmail.com

Copyright: ( $\odot$ the author(s), publisher and licensee Medip Academy. This is an open-access article distributed under the terms of the Creative Commons Attribution Non-Commercial License, which permits unrestricted non-commercial use, distribution, and reproduction in any medium, provided the original work is properly cited.

\section{ABSTRACT}

Following January 2020, the SARS-COV-2 spread worldwide, ravaging health systems and causing widespread disruptions in the economic and social spheres. Successive waves of the COVID-19 pandemic in different countries concluded that the fight against the virus will be prolonged. Countries including India tried to reduce the spread of SARS-COV-2 by inducing restrictions on population mobility, high testing rates and dynamic algorithmic management but vaccination remained the only definitive answer against SARS COV-2. Though India started its vaccination program in a phased manner as early as January 2021, the second covid wave thwarted its gains with Indian facing a triple whammy of high incident cases, overburdened health infrastructure and inelastic vaccine supplies. In this review, we examined the strength, weakness, opportunities and threats (SWOT) of India's vaccination programme and also suggest solutions to augment its strengths, manage its weakness, consolidate on opportunities and neutralise threats with effective measures of priority vaccination in high-risk districts, war footing immunisation, emergency use authorisation of vaccines, expanding vaccination programme to include children above 12 years and countering vaccine hesitancy with fact and reason. The review concluded that by strategic immunisation of high priority/high-risk districts the upcoming third wave can be thwarted if not completely prevented at a lower economic and social cost.

Keywords: Vaccination, India, SWOT, SARS COV-2, COVID-19, Challenges

\section{INTRODUCTION}

The COVID-19 is an infectious disease caused by a newly discovered coronavirus SARS-CoV-2, which spread rapidly throughout the world from the Wuhan province of China from January 2020. In March 2020, the WHO declared the COVID-19 outbreak a pandemic. Following which successive waves of SARS-COV-2 infection occurred in different parts of the globe ravaging health systems, leading to economic catastrophe and affecting human development. Though several countries, including India, took strong measures to contain the spread of COVID-19 through measures like lockdown, social distancing, high testing, containment and syndromic management, it is agreeable now that vaccinating a sufficiently large population will provide a lasting solution by enhancing immunity and containing the spread of the disease. ${ }^{1}$

The vaccines which were under clinical evaluation in India require two doses to be administered four weeks to 12 weeks apart, through the intramuscular route. ${ }^{1}$ Anticipating the COVID-19 vaccine roll out the government of India (GoI) was bestowed with the magnanimous task of expeditiously vaccinating its large population. One of the milestones in this direction was 
the constitution of a national expert group on vaccine administration for COVID-19 (NEGVAC) a technical group of experts to guide on all aspects of the COVID-19 vaccination programme in India. ${ }^{1}$

Countries like the US, UK started their vaccination programme earlier in early to mid-December. ${ }^{2,3}$ In India the COVID-19 vaccination programme was introduced on 16 January 2021 in three phases through prioritisation of beneficiaries in following order phase 1 included approximately 1 crore healthcare workers, phase 2 included 2 crore frontline workers and phase 3 included prioritised population of elderly and those with morbidities. $^{1}$

The successful introduction of the COVID-19 vaccination programme will largely depend upon the availability of effective vaccine commensurate with the demand, a dedicated and trained workforce, logistics, trained enumerators for beneficiary listing, the mobilisation of health functionaries for vaccination activities, social mobilisation through the involvement of local leaders, NGOs and community based organisations and finally advocacy of vaccination through mass media and social media.

In this context, the present communication attempts to do a situation analysis of the readiness of India's healthcare system for implementing the COVID-19 vaccination programme, identify the various bottlenecks and suggest possible solutions for the successful implementation of the programme.

\section{CURRENT STATUS OF IMPLEMENTATION OF COVID-19 VACCINATION PROGRAMME IN INDIA}

As on 31 May 2021, 16,86,13,371 (12.1\%) people have been administered single dose of vaccine while $4,45,40,758(3.2 \%)$ both the doses. ${ }^{4}$ The two vaccines that have been granted emergency use authorization by the central drugs standard control organization (CDSCO) in India are Covishield ${ }^{\circledR}$ (AstraZeneca's vaccine manufactured by Serum Institute of India) and Covaxin ${ }^{\circledR}$ (manufactured by Bharat Biotech Limited). The COVID19 vaccine intelligence network (Co-WIN) system, a digital platform is being used to track the enlisted beneficiaries for vaccination and COVID-19 vaccines on a real-time basis.

According to the guidelines issued by the ministry of health and family welfare (MoHFW), people are advised to register on the Co-WIN app and receive the vaccine from government and private health facilities as notified, known as COVID vaccination centres (CVCs). Those who cannot get themselves registered online can contact their local government health workers, who will help the beneficiaries to the government CVC for on the spot registration, appointment, verification and vaccination on the same day.
Based on the potential availability of vaccines the government of India has selected the priority groups who will be vaccinated on priority as they are at higher risk. The first group includes healthcare and frontline workers. The second group to receive the COVID-19 vaccine will be persons over 60 years of age and persons between 45 and 59 years of age with comorbid conditions. ${ }^{5}$

Presently, as India desperately tries to control a deadly second wave of the novel coronavirus amid warnings of a third wave, many experts have said that fast vaccination is the only long-term solution for India. However, vaccination numbers have been falling of late because of inefficient planning as well as a dearth of supply.

India's daily COVID-19 shots have fallen sharply from an all-time high reached early last month as domestic companies struggle to boost supplies and imports are limited, even as the country fights the world's worst surge in infections. Daily inoculations have averaged 2.5 million since hitting a peak of 4.5 million on April 5. A quadrupling of coronavirus cases during the period has collapsed the public health system in many regions of the country. ${ }^{7}$

More than 13 million people aged 18-45 have registered for the jab, but states including central Madhya Pradesh and hard-hit Maharashtra have said they would not start vaccinating this age group on 1 May as planned due to supply problems. Many states have announced that they can't begin the vaccination drive as the manufacturers have not been able to keep up with demand. ${ }^{8}$ One estimate has suggested that at the present rate India will take 10.8 years to administer both doses to 70 percent of its population to attain herd immunity. ${ }^{9}$

Vaccine production in India is expected to benefit from the financial support announced by the Quad nations to increase COVID-19 vaccine manufacturing by 1 billion doses. The stock of items such as syringes and gloves for the frontline healthcare workers is to be aligned with the expected increase in vaccine production in India in the next two years. ${ }^{10}$

Currently, cold chain infrastructure is highly concentrated in urban areas. The inter-state disparity in the distribution of cold-chain points is another area that needs to be focused on to overcome challenges associated with vaccine distribution. With an increasing number of COVID-19 cases in several states due to the second wave of the virus, a wider vaccination program is becoming critical for controlling its spread. ${ }^{10}$

After considering these issues which may have a direct or indirect bearing on the effective implementation of the COVID-19 vaccination programme, here we attempted a SWOT analysis of the vaccination programme in India. 


\section{STRENGTHS}

\section{Robust primary health care system}

The primary health care system in India has evolved since independence and there is an elaborate network of nearly 200,000 government primary health care facilities (GPHCFs), both in rural and urban areas. ${ }^{11}$

\section{Well-trained healthcare cadre}

With over 25 lakh aanganwadi workers, 10 lakh ASHA workers, 27079 health assistants with 219326 ANM India has a dedicated cadre of grass-root works that form a backbone of India's public healthcare. Judicious utilisation of their services in the vaccination programme will be instrumental in achieving high vaccination coverage in the upcoming months. ${ }^{11}$

\section{Vaccine distribution, logistics are supply chains}

One of the important factors which determine the timely supply of vaccines from the site of manufacture to different states is the logistics network availability. An adequate supply chain and logistics infrastructure, realtime visibility along the supply chain, micro-level planning to organize the administration of vaccines, effective planning and coordination among the agencies involved in vaccine administration are some of the factors expected to assist in overcoming vulnerabilities in the vaccine supply chain. India's vaccine distribution is a robust network operated through four government medical store depots (GMSDs) in Karnal, Mumbai, Chennai and Kolkata which procure vaccines from the manufacturers. About 53 state vaccine stores get their supplies either from these GMSDs or directly from manufacturers. $^{12}$

\section{Strong administrative and legal machinery}

The Union Ministry of Health and Family Welfare is responsible for the implementation of various programs on a national scale in the areas of health and family welfare. In addition, the ministry assists states in preventing and controlling the spread of seasonal disease outbreaks and epidemics through technical assistance. ${ }^{13}$ The epidemics act 1897 and the disaster management act of 2005 give a strong legislative framework for controlling the spread of diseases and streamlining roles of various government agencies during a disaster.

\section{WEAKNESSES}

\section{Snail pace of vaccination}

India's daily vaccine doses have fallen steadily over the month of April and May. As of May 15, India's 7 days moving average of vaccination is 18,73,005 doses for the preceding week. ${ }^{14}$ At such rate of vaccination India will reach only 35 to $40 \%$ immunised population by midNovember (Figure 1).

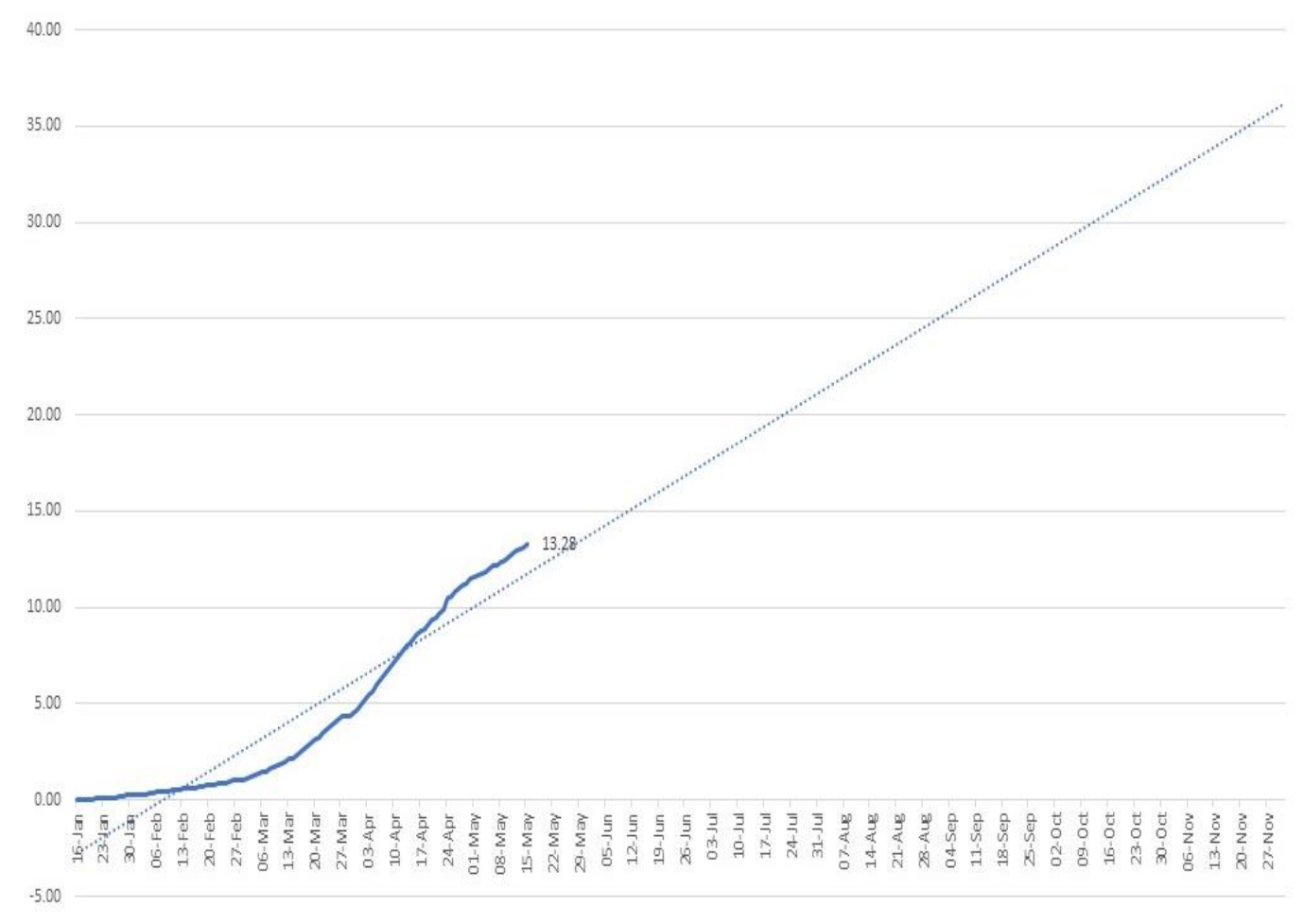

Figure 1: Linear projection of the population that will be vaccinated at the current pace of vaccination. 


\section{In elastic vaccine production capacities not being able to meet the demand}

Presently, two private Indian vaccine manufacturers, Serum Institute of India (SII) and Bharat Biotech are struggling to meet India's domestic demand of 90 million doses every month besides their other contractual obligations. But they are producing about 70 million doses per month, which is considerably below the required quantity. ${ }^{15}$

\section{Bureaucratic hurdles}

The Indian bureaucracy considered bulwark of India's public administration has always delivered on the ideals of the constitution of India. But recently, there has been criticism of the bureaucracy regarding inordinate delay in decision making. ${ }^{16}$ This systemic fallibility has been brought to the fore during this pandemic which required fast-tracking of technical inputs to be transmitted more efficiently at ground level and eliciting better coordinator among different sectors.

\section{Trade-off between lives and livelihood}

Having to choose between life and livelihood is a grim situation for a country to be in. Governments can take care of livelihood concerns by getting food and money across to people, while they continue with a lockdown and use that time to add health facilities to brace for the rising tide of COVID-19 cases. It is important to stem that tide because it will hit at the heart of both life and livelihood. ${ }^{17}$

\section{OPPORTUNITIES}

\section{Short term}

India has successfully overcome the dreaded smallpox in the late 1970s and the crippling poliomyelitis in 2014 through mass vaccination programmes. It also runs the world's largest immunisation programme in the world through a dedicated network of well-coordinated immunisation centers which reaches the last person. If India is successful in vaccinating its population in a short period, it will be the greatest achievement in the history of public health and a role model to other nations.

\section{Long term}

The pandemic has also allowed strengthening the heathcare infrastructure and human resources through increased capital expenditure on health beyond the envisaged $2.5 \%$ of GDP by 2030 . Healthcare spending on universal health coverage and social security measures will be yielding greater dividends if the majority of the population is covered with affordable health insurance programmes.

\section{THREATS}

\section{An upcoming third wave of COVID-19 infection}

According to the 'SUTRA model' created by experts at IIT-Kanpur it is projected that the third wave of COVID19 cases is expected in 6-8 months. The impact of the third wave can be cushioned if an adequate number of people are vaccinated. ${ }^{18}$

\section{Vaccine hesitancy among the population}

The WHO defines vaccine hesitancy as a delay in acceptance or refusal of vaccines despite availability of vaccination services. ${ }^{19}$ It involves a complex mix of cultural, psychosocial, spiritual, political and cognitive factors. ${ }^{20} \mathrm{~A}$ significant portion of the population with vaccine hesitancy for COVID-19 vaccine poses a significant threat to both the individual and their community, since exposure to a contagious disease like COVID-19 places the person at risk and individuals are far more likely to spread the disease to others if they do not get vaccinated.

\section{A high migrant population difficult to track}

As per the census, India had 45.6 crore migrants in 2011 ( $38 \%$ of the population) compared to 31.5 crore migrants in 2001 (31\% of the population). Between 2001 and 2011 , while the population grew by $18 \%$, the number of migrants increased by $45 \%$. In $2011,99 \%$ of total migration was internal and immigrants (international migrants) comprised $1 \% .{ }^{21}$ It is a humongous task to keep track of such large numbers of migrants for the COVID19 vaccination programme especially with frequent lockdowns and unlocking of cities to tackle the pandemic.

\section{Non-universal observance of COVID-appropriate behaviour}

Central teams have reported non-adherence of COVID-19 appropriate behaviour in almost all of the 50 most affected districts in Maharashtra, Chhattisgarh and Punjab, the union health ministry said advising the states to more strictly enforce norms to prevent the spread of coronavirus. Of the 50 districts most affected by COVID19, 30 are in Maharashtra, 11 in Chhattisgarh and nine in Punjab. $^{22}$

\section{Fear of a replicating virus turning into a new mutation}

Although it wasn't noticed at the time, the mutant B.1.617.2 had been sequenced and its genetic code deposited in the global database as early as October 2020. This new variant (designated as the delta strain) has spread fast, causing more than 60 percent of all coronavirus infections in the Indian state of Maharashtra alone. ${ }^{23,24}$ Fear of a new mutation that will escape vaccine efficacy and acquired immunity looms large if people are 
not vaccinated faster enough to control the spread of infection.

\section{SUGGESTED SOLUTIONS FOR EFFECTIVE IMPLEMENTATION OF THE COVID-19 VACCINATION PROGRAMME}

\section{Strategic immunisation}

When the COVAX alliance co-led by CEPI, GAVI and WHO alongside key delivery partner UNICEF came into existence it aimed to accelerate the development and manufacture of COVID-19 vaccines and to guarantee every country in the world fair and equitable access to vaccines. $^{25}$ Unfortunately, the COVAX is severely underfunded and hampered by vaccine hoarding in highincome countries with only 1.1 billion doses of vaccine purchased by it as compared to the 4.6 billion doses bought by high-income nations. ${ }^{26}$ India which believes in the idea of vasudhaiva kutumbakam (the world is one family) through its humanitarian and commercial initiative of vaccine maitri has been instrumental in providing 64.5 million doses of COVID-19 vaccines to 95 countries around the world. ${ }^{27}$ Following the second wave of COVID-19, India had to curb vaccine exports as cases surged and domestic vaccine shortfall was evident.

In event of such an inelastic vaccine supply, we suggested that strategic immunization should be carried out through prioritisation of vaccination in those districts which had the highest burden of cases and deaths in both the COVID-19 waves.

Figure 2 and 3 shows that in both the COVID-19 waves (24 March 2020 to 1 October 2020) and (1 March 2021 to 15 May 2021) similar districts were affected. ${ }^{14}$ Districts like Mumbai, Delhi, Chennai, Pune, Bengaluru urban continue to record the highest cumulative cases and deaths even in the second covid wave because of their previously well-researched factors like high population density, high mobility, high rural-urban migration and more interconnected social networks could well be turned high risk or hot spots districts. ${ }^{28-31}$

\section{Districts with Highest Cumulative cases (1st March 2021- 15th May 2021)} 2020)
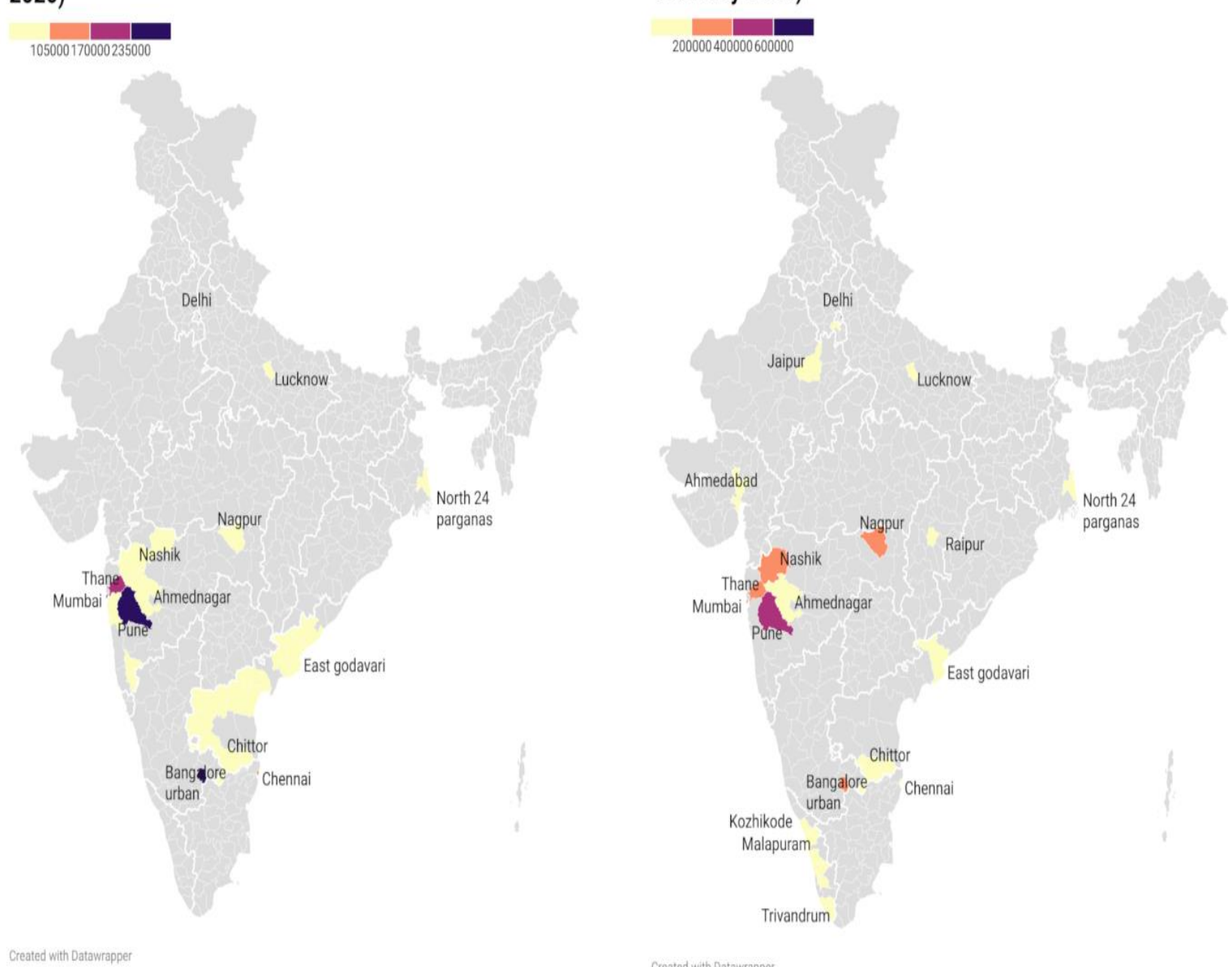

Figure 2: Similarity of districts reporting the highest number of SARS COV-2 in both waves. 


\section{Districts with Highest Deaths (24 March 2021-1st October} 2020)

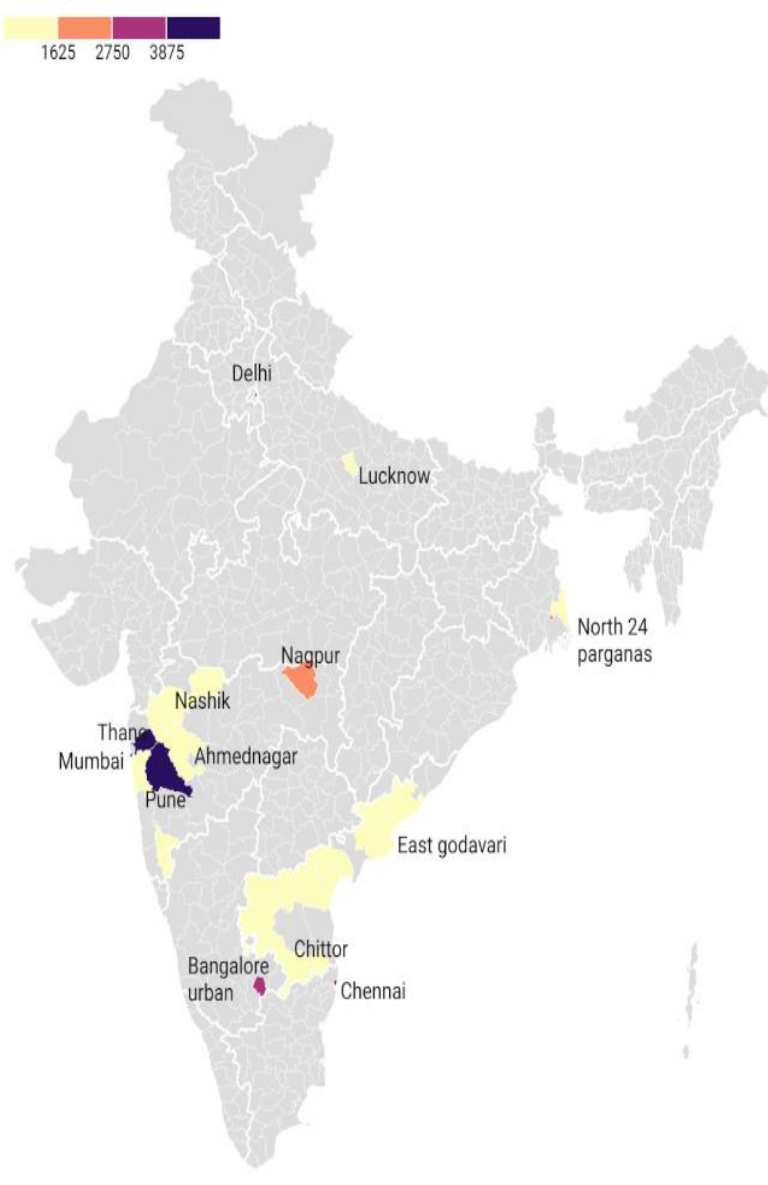

\section{Districts with Highest death (1st March 2021-15th May} 2021)

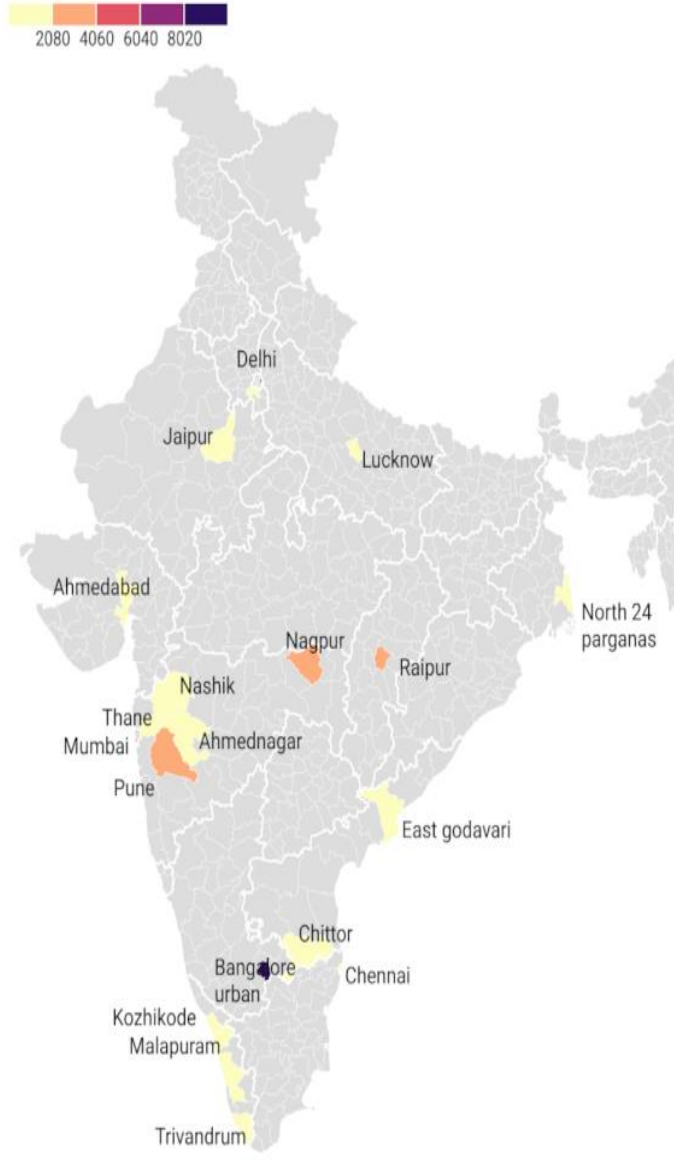

Figure 3: Similarity of districts reporting high COVID-19 related deaths in both the waves.

Table 1: Comparison of cases and deaths in both the COVID-19 waves in the highest 25 districts. ${ }^{14}$

\begin{tabular}{|lll|}
\hline Comparison & $\begin{array}{l}\text { 1st COVID wave } \\
(\mathbf{2 4} \text { March to 1 October }\end{array}$ & $\begin{array}{l}\text { 2nd COVID wave } \\
\text { (1 March to 15 May 2021) }\end{array}$ \\
\hline Cumulative cases in India & 6391480 & 13558915 \\
\hline Cumulative cases of 25 districts & 2481248 & 4881679 \\
\hline \% of cases contributed by these 25 districts & 38.8 & 36.0 \\
\hline Cumulative deaths in India & 99806 & 113033 \\
\hline Cumulative deaths in 25 districts & 47667 & 43037 \\
\hline \% of deaths contributed by these 25 districts & 47.8 & 38.1 \\
\hline
\end{tabular}

These 25 districts cumulatively contributed to $38.8 \%$ of COVID-19 cases and $47.7 \%$ of COVID-19 deaths in the first wave and $36 \%$ and $38 \%$ of cases and deaths respectively in the second wave (Table 1).

Secondly, these hot spot districts also serve as draining areas for the adjacent districts because of their employment opportunities. The resultant spill-over effect of infections from high-risk districts is transmitted to these adjacent districts (satellite districts) which also continue to record higher infections in case of a rise in hot spots/high-risk districts. For example, the Thane district of Maharashtra is closely interconnected to the Mumbai district through well-developed transport networks. Also, Chengalpattu and Tiruvallur district in Tamil Nadu are in close transport proximity to Chennai report higher cases than other districts. ${ }^{14}$ 
So, if the inelastic vaccine supply continues and vaccine allocation is carried out proportionately according to the population, these high-risk districts will not get sufficient doses to achieve threshold herd immunity, leading to a high burden of the unimmunized population which are susceptible to infection and rapid spread of the disease.

The economic, social and psychological cost of SARSCOV-2 spread is higher for high-risk/hot spot districts than others. ${ }^{32}$ The report by Mumbai based care ratings states that potential loss of 40000 crores gross value added (GVA) took place in the phase of current lockdown since April 5 in the state of Maharashtra. ${ }^{33}$ Once universal immunisation is carried out in these high-risk districts, these districts can go back to their pre-pandemic levels of livelihoods and economic growth.

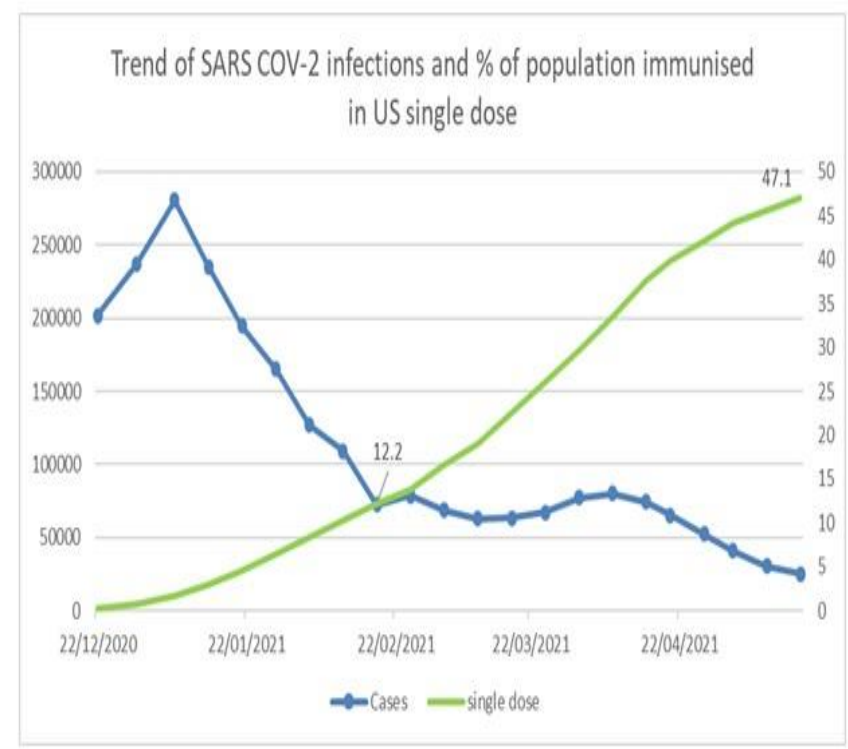

\section{Trend of SARS COV - 2 infections and \% of Population} immunised by single dose in israel

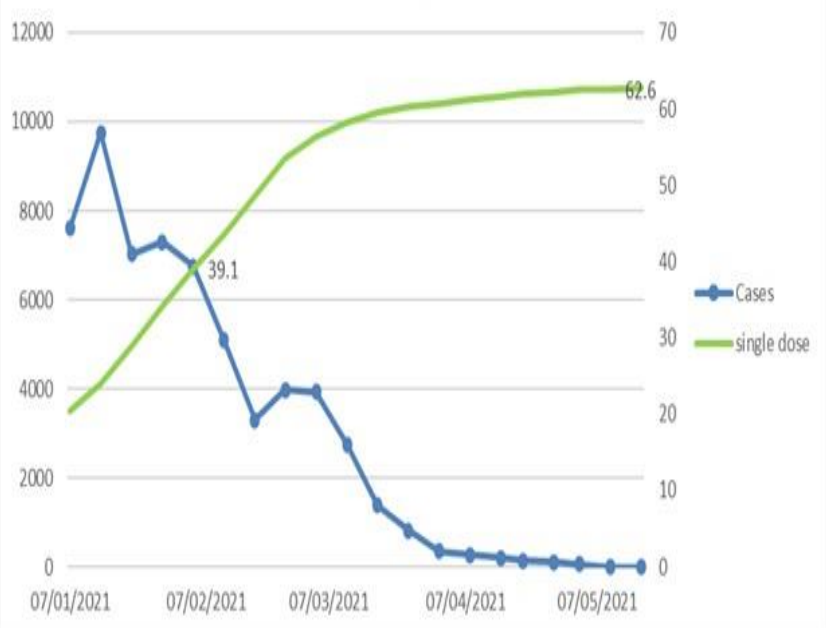

Potential benefits of this strategy after a threshold population herd immunity is achieved include primarily a break in the chain of transmission, a faster reduction of daily incident cases and deaths, reduction in clustering of cases, reduce spiller over effect in adjacent districts, reduce population pressure on health human resource and infrastructure, reduce the use of lockdown as a preventive measure to control the outbreak, faster resumption of economic activities and sustainable livelihoods, resumption of international travel, trade and tourism.

\section{War footing immunisation}

Data from the United States, United Kingdom, Israel and other countries suggests that vaccination with the high rate of vaccination infections and deaths related to COVID-19 can be brought down (Figure 4). ${ }^{34}$

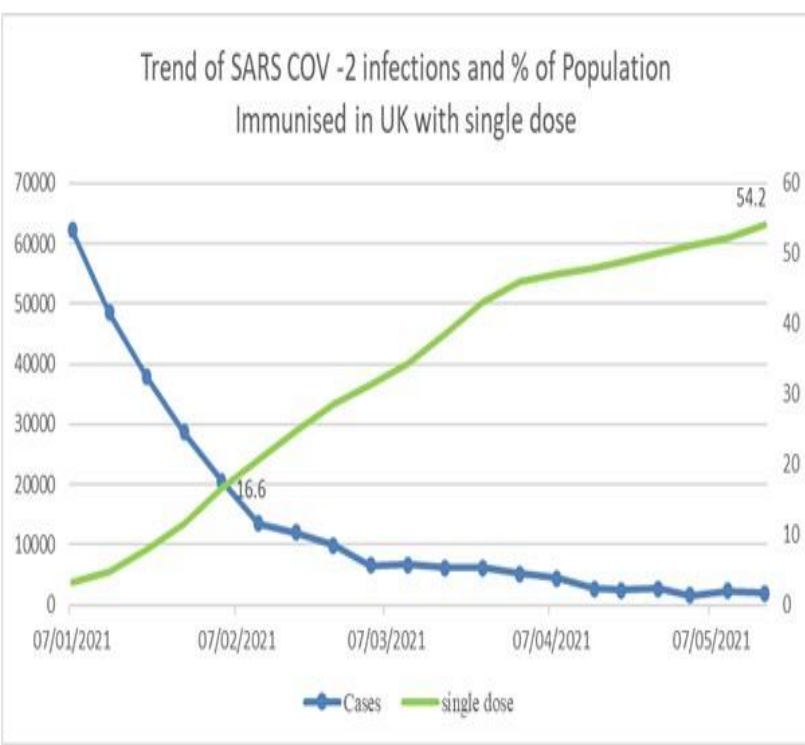

\section{Trend of SARSCOV-2Infection and \% of Population Immunised in India with a single dose}

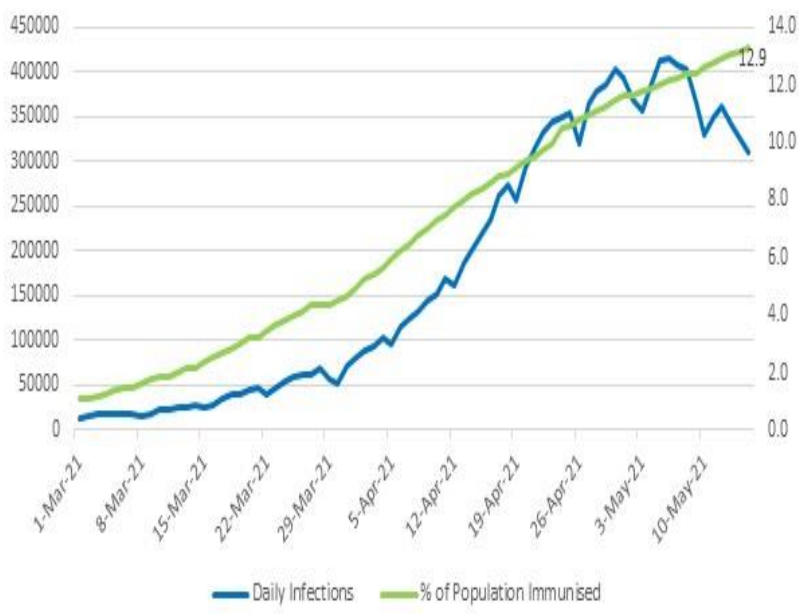

Figure 4: Trend of SARS COV-2 Daily cases and \% of Population Immunised by a single dose. 
The government should make vaccination of citizens the priority as a policy above anything else. This snail's pace of vaccination will hamper any attempt at acquiring threshold herd immunity. Vaccination programme can go $24 \times 7$ hours in major cities which do have adequately trained staff for this process. ${ }^{35}$

In cities, there should be aggregated in 5-10 jumbo vaccination centers which can vaccinate 1 lakh people per day. This will save the cost of travel, logistics, maintain the cold chain and efficacy of the vaccine and streamline vaccine procedures.

The role of the private sector cannot be overemphasized here. Multinational companies can procure vaccines from the manufacture at agreed commercial costs and vaccinate their employees under corporate social responsibility (CSR) or even under their health insurance package. ${ }^{36}$ Some states and cities shave started mohalla or community vaccination which is a welcome step and will go a long way in achieving high coverage and reduce wastage. $^{37,38}$

\section{Emergency use authorisation of vaccines with proved efficacy}

The drug controller of India (DGCI) should consider emergency use authorisation (EUA) for more who listed vaccines like the Pfizer/Biontech, Astrazeneca-SK Bio, Serum Institute of India, Janssen and Moderna vaccines for emergency use as these are proved to be a success in bringing down the pandemic in US, UK, Israel and other countries. $^{34,39}$ The focus should be on having more vaccines in the armour so that vaccine supply is commensurate to the demand. For example, if 5 crore doses of 5 different vaccine manufacturers are available every month, India will be able to immune 12.5 crore people and archive threshold herd immunity of $67 \%$ (assuming the highest R0-3 for SARS-COV-2) in the next 6 months.

The mRNA vaccines which require storage below minus 18 degrees may not be feasible for administration in rural areas or district headquarters. These vaccines can be utilised in metropolitan cities where cold storage facilities and logistics are easily available and the population has purchasing power to access these vaccines.

\section{Inclusion of population of between 12-18 years in the vaccination programme}

The CDC recommends everyone 12 years and older should get a COVID-19 vaccination to help protect against COVID-19 as widespread vaccination is a critical tool to help stop the pandemic. ${ }^{40}$ Countries like Dubai and Japan have started vaccinations. ${ }^{41}$ India cannot afford to leave $41 \%$ of the population less than 18 years of age unimmunised as it will not be able to achieve herd immunity and prone to repeated waves of infection. ${ }^{42}$
Here we suggested the inclusion of the 12-18 year population under the COVID-19 vaccination programme.

\section{Countering vaccine hesitancy with fact and reason}

The state governments should take up the initiative of advocating the benefits of vaccines through building vaccine confidence by involving various stakeholders like the beneficiaries, public administrators, community-based organisations, socio-religious organisation, local political leaders, NGOs and most importantly women self-help groups. It can spread spell out vaccine success stories in other countries through effective mass media and social media communication. It can root in popular celebrities, politicians to advocate for vaccination to dispel the associated rumors and fear. We can encourage leaders in family, community or organizations to be vaccine champions which can help educate people about COVID19 vaccines, how they are manufactured and monitored for safety. ${ }^{43}$

\section{Wastage}

The national average of COVID-19 wastage is $6.5 \%$ on average. While vaccine shortage has hampered the COVID-19 vaccination program in several states, vaccine wastage is as high as $37.3 \%$ in Jharkhand (37.3\%), 30.2\% in Chhattisgarh and $15.5 \%$ in Tamil Nadu. ${ }^{44}$ Wastage, in general, occurs at three levels, during transportation, during cold chain point and at a vaccination site-both at service and delivery levels. Daily vaccination drives must be well mobilized and planned, vials must be opened only after 10 beneficiaries arrive, adequate training must be given to healthcare workers on how to draw doses, rumors and misinformation about vaccines must be dealt with strictly and cold chain system must be maintained properly.

\section{Compulsory vaccine certificate/passport to attend public gatherings and in-migration}

Subsequent universal immunisation of a particular geographic area, the local governments should ensure that people attending a public gathering or in migrating should have vaccination certificate to prevent the outbreak of diseases.

\section{CONCLUSION}

History has taught us during smallpox eradication and polio elimination that a united response in a large and geographically diverse country like India is possible to overcome a common enemy.

Prioritizing high-risk districts for vaccination, the establishment of jumbo vaccination centers, enforcement of compulsory vaccination certificates, achieving involvement of the private sector will go a long way in increasing coverage of the vaccination programme. The governments need to take proactive decisions to 
overcome vaccine hesitancy and wastage which at times might infringe upon individual autonomy but are essential in the interest of larger public good and which are well spelled out in Article 19 subclause 2(A) of the constitution of India.

Fast tracking of proven vaccines and import of vaccines from other countries cutting short the red-tapism is another key activity at the regulatory level which ensures quick availability of the vaccine to the target population. The SARS COV-2 virus is moving fast. We must move faster. Finally, we firmly believe in what the famous German philosopher G. W. F. Hegel said, 'The state is the march of God on Earth' and will be able to tide us over the present crisis.

Funding: No funding sources

Conflict of interest: None declared

Ethical approval: Not required

\section{REFERENCES}

1. COVID 19 vaccines-operations guidelines. Ministry of Health and Family Welfare. Government of India updated as of 28/12/2020: Delhi; 2020. Available at https://covid19.india.gov.in/document-category /ministry-of-health-and-family-welfare/page/15/.

Accessed on 12 May 2021.

2. National. Fact sheet: The weapon that will end the war: first coronavirus vaccine shots given outside trials in U. S. Available at: https://www.washingtonpost.com/nation/2020/12/14 /first-covid-vaccines-new-york/. Accessed on 11 May 2021.

3. BBC News. Fact sheet: COVID-19 vaccine: firstperson receives Pfizer jab in the UK, 2020. Available at: https://www.bbc.com/news/uk55227325. Accessed on 11 May 2021.

4. Ministry of Health and Family Welfare. Fact sheet: Cumulative coverage report of COVID-19 vaccination, government of India, 2021. Available at: https://www.mohfw.gov.in/. Accessed on 11 May 2021.

5. COVID-19 Vaccine communication strategy. Ministry of Health and Family Welfare, Government of India updated 25/03/2021: Delhi;2021. Available at https://www.mohfw.gov.in .Accessed on 21st May 2021

6. The Economic Times. Fact sheet: Short of shots: where does India stand currently on vaccine supply? Available at: https://economictimes.indiatimes.com/industry/healt hcare/biotech/pharmaceuticals/short-of-shots-wheredoes-india-stand-currently-on-vaccinesupply/articleshow/82540241.cms?utm_source=cont entofinterest\&utm_medium=text\&utm_campaign=c ppst. Accessed on 11 May 2021.

7. The Economic Times. Fact sheet: India's vaccinations plummet as coronavirus infections soar, 2021. Available at: https://economictimes.indiatimes.com/news/india/in dias-vaccinations-plummet-as-coronavirus-

infectionssoar/articleshow/82373922.cms?utm_sour ce $=$ contentofinterest\&utm_medium $=$ text\&utm_cam paign=cppst. Accessed on 12 May 2021.

8. BBC News. Fact sheet: India coronavirus: over-18s vaccination drive hit by shortages, 2021. Available at: https://www.bbc.com/news/world-asia-india56345591. Accessed on 12 May 2021.

9. Business Today. Fact sheet: COVID-19 vaccination: at the current rate, India will take 10.8 years to vaccinate $70 \%$ population, 2021. Available at: https://www.businesstoday.in/coronavirus/covid-19vaccination-current-rate-india-take-12-yearsvaccinate-70pc-population/story/433737.html. Accessed on 12 May 2021.

10. The Growth Pipeline Company. Fact sheet: Frost and Sullivan highlights current status and key challenges in COVID-19 vaccine logistics in India. Available at: https://ww2.frost.com/frostperspectives/frost-sullivan-highlights-current-statusand-key-challenges-in-covid-19-vaccine-logisticsin-india/. Accessed on 12 May 2021.

11. National Health Profile 2019. Central Bureau Of Health Intelligence Dghs. Ministry of Health and Family Welfare, Delhi: 2021, P.231. Available at http://www.cbhidghs.nic.in/showfile.php?lid=1147 .Accessed on 21st May 2021

12. Mint. Fact sheet: India's vaccine distribution challenge, explained in five charts, 2020. Available at: https://www.livemint.com/news/india/india-svaccine-distribution-challenge-explained-in-fivecharts-11607106132744.html. Accessed on 12 May 2021.

13. Choksi M, Patil B, Khanna R, Neogi SB, Sharma J, Paul VK, et al. Health systems in India. J Perinatol. 2016;36:9-12.

14. COVID19-India. Fact sheet: A volunteer-driven, crowd-sourced database for COVID-19 stats and patient tracing in India. Available at: https://www.covid19india.org/. Accessed on 12 May 2021.

15. National Herald. Fact sheet: State-owned vaccine manufacturers sit idle as India scours for jabs: Report, 2021. Available at: https://www.nationalheraldindia.com/india/stateowned-vaccine-manufacturers-sit-idle-as-indiascours-for-jabs-report. Accessed on 12 May 2021.

16. Daily. Fact sheet: How political interference, corruption and outdated procedures have crippled India's bureaucracy, 2018. Available at: https://www.dailyo.in/politics/indian-bureaucracybabus-corruption-political-interference-narendramodi/story/1/26779.html. Accessed on 12 May 2021.

17. Business Line. Fact sheet: The toss-up between life and livelihood, 2020. Available at: https://www.thehindubusinessline.com/opinion/thetoss-up-between-life-and- 
livelihood/article31850978.ece. Accessed on 12 May 2021.

18. India Today. Fact sheet: Covid second wave to end in July, third wave after 6 months: Expert panel, 2021. Available

https://www.indiatoday.in/coronavirus-

outbreak/story/covid-second-wave-end-july-thirdwave-six-months-govt-panel-1804512-2021-05-19. Accessed on 12 May 2021.

19. MacDonald NE, SAGE Working Group on Vaccine Hesitancy. Definition, scope and determinants. Vaccine. 2015;33(34):4161-4.

20. Dubé E, Laberge C, Guay M, Bramadat P, Roy R, Bettinger J. Vaccine hesitancy: an overview. Hum Vaccin Immunother. 2013;9(8):1763-73.

21. Census, 2011. Office of the Registrar General \& Census Commissioner, Ministry of Home Affairs. Available at https://www.prsindia.org/theprsblog/ migration-india-and-impact-lockdownmigrants\#_edn1.Acessed on 21st May 2021

22. India Today. Fact sheet: Covid appropriate behaviour not being followed in 50 most-affected districts in 3 states Govt. Available at: https://www.indiatoday.in/coronavirusoutbreak/story/covid-appropriate-behaviour-notbeing-followed-in-50-most-affected-districts-in-3states-govt-1789823-2021-04-1. Accessed on 12 May 2021.

23. National Geographic. Fact sheet: This double mutant variant is adding fuel to India's COVID-19 crisis, 2021. Available at: https://www.nationalgeographic.com/science/article/ this-double-mutant-variant-is-adding-fuel-to-indiascovid-19-crisis. Accessed on 12 May 2021.

24. India Today. Fact sheet: WHO assigns labels to covid variants, strain first found in India to be called Delta, 2021. Available at: https://www.indiatoday.in/coronavirusoutbreak/story/who-names-labels-mutant-strainscorona-india-covid-strain-delta-1809235-2021-0531. Accessed on 12 May 2021.

25. WHO. Fact sheet: Role of COVAX, 2021. Available at: https://www.who.int/initiatives/act-accelerator/ covax. Accessed on 12 May 2021.

26. Devex. Fact sheet: Is COVAX part of the problem or the solution? 2021. Available at: https://www.devex.com/news/is-covax-part-of-theproblem-or-the-solution-99334. Accessed on 12 May 2021.

27. Ministry of External Affairs. Fact sheet: Vaccine Maitri, 2021. Available at: https://www.mea. gov.in/vaccine-supply.htm. Accessed on 12 May 2021.

28. Yin H, Sun T, Yao L, Jiao Y, Ma L, Lin L, et al. Association between population density and infection rate suggests the importance of social distancing and travel restriction in reducing the COVID-19 pandemic. Environ Sci Pollut Res Int. 2021:1-7.
29. Suryawanshi D, Venugopal R, Goyal R. Factors influencing COVID-19 case burden and fatality rates findings from secondary data analysis of major urban agglomerations in India. Int $\mathrm{J}$ Commun Med Pub Health. 2020;7(8):3284-92.

30. Jo W, Chang D, You M, Ghim G. A social network analysis of the spread of COVID-19 in South Korea and policy implications. Sci Rep. 2021;11:8581.

31. Kartal MT, Depren O, Depren SK. The relationship between mobility and COVID-19 pandemic: Daily evidence from an emerging country by causality analysis. Transport Res Interdisciplin Perspect. 2021;10:100366.

32. Chu IY, Alam P, Larson HJ, Lin L. Social consequences of mass quarantine during epidemics: a systematic review with implications for the COVID-19 response. J Trav Med. 2020;27(7):192.

33. Maharashtra lockdown to shave off $0.3 \%$ growth. Mumbai Care Ratings. Available at https://www.careratings.com/. Accessed on 31 May 2021.

34. Our World in Data. Fact sheet: Coronavirus (COVID-19) vaccinations, 2020. Available at: https://ourworldindata.org/covid-vaccinations. Accessed on 12 May 2021.

35. The Hindu. Fact sheet: Coronavirus vaccine can be taken 24/7, says Centre, 2021. Available at: https://www.thehindu.com/news/national/coronaviru s-vaccine-can-be-taken-247-sayscentre/article33982860.ece. Accessed on 12 May 2021.

36. The Economic Times. Fact sheet: India Inc works on getting all employees inoculated, sourcing jabs for in-house drives, 2021. Available at: https://economictimes.indiatimes.com/news/compan y/corporate-trends/india-inc-works-on-getting-allemployees-inoculated/articleshow/82283084. cms?utm_source $=$ contentofinterest\&utm_medium $=\mathrm{t}$ ext\&utm_campaign=cppst. Accessed on 12 May 2021.

37. The Times of India. Fact sheet: Door-to-door outreach, street plays planned to boost Dharavi vax drive, 2021. Available at: https://timesofindia. indiatimes.com/city/mumbai/mumbaidoor-to-dooroutreach-street-plays-planned-to-boost-dharavi-vaxdrive/articleshow/81639587.cms. Accessed on 12 May 2021.

38. The Hindu. Fact sheet: Special vaccination camps at 200 locations for the 18-44 age group in Chennai, 2021. Available at: https://www.thehindu.com/ news/cities/chennai/coronavirus-specialvaccination-camps-at-200-locations-for-18-44-agegroup-in-chennai/article34640185.ece. Accessed on 12 May 2021.

39. WHO. Fact sheet: WHO lists additional COVID-19 vaccine for emergency use and issues interim policy recommendations, 2021. Available at: https://www.who.int/news/item/07-05-2021-wholists-additional-covid-19-vaccine-for-emergency- 
use-and-issues-interim-policy-recommendations.

Accessed on 12 May 2021.

40. CDC. Fact sheet: COVID-19 vaccines for children and teens, 2021. Available at: https://www.cdc. gov/coronavirus/2019-ncov/vaccines/recommenda tions/adolescents.html. Accessed on 12 May 2021.

41. The Economic Times. Fact sheet: Dubai offers Pfizer vaccine to 12-15-year-olds, 2021. Available at:

https://economictimes.indiatimes.com/news/internati onal/uae/dubai-offers-pfizer-vaccine-to-12-15-yearolds/articleshow/83140554.cms. Accessed on 12 May 2021.

42. Office of the Registrar General and Census Commissioner, Ministry of Home Affairs. Fact sheet: Age structure and marital status, 2021. Available at: https://censusindia.gov.in/census_and_ you/age_structure_and_marital_status.aspx.

Accessed on 12 May 2021.
43. Office of the Registrar General and Census Commissioner, Ministry of Home Affairs. Fact sheet: Building confidence in COVID-19 vaccines, 2021. Available at: https://www.cdc .gov/vaccines/covid-19/vaccinate-withconfidence.html. Accessed on 12 May 2021.

44. The Indian Express. Fact sheet: Explained: understanding Covid-19 vaccine wastage in India, 2021. Available at: https://indianexpress. com/article/explained/covid-vaccine-wastage-pmmodi-coronavirus-inoculation-drive-7236405/. Accessed on 12 May 2021.

Cite this article as: Suryawanshi DM, Venugopal R, Anbazhagan S, Rajseharan D, Kumar G. India's COVID-19 vaccination programme: challenges and solutions. Int J Community Med Public Health 2021;8:3677-87. 